\title{
A study on disease dynamics of covid-19 in different states of India:A data driven analysis of the available evidence
}

\begin{abstract}
Backgrounds: Case Fatality Ratios (C.F.R.) in neighbouring countries recently varied widely, with highest being in Afghanistan (2.43\%), followed by Pakistan $(2.05 \%)$, Bangladesh (1.26\%), Sri Lanka (0.54\%), Maldives $(0.38 \%)$, and Nepal $(0.21 \%)$. This study-based on analysis of COVID-19 data from India, was undertaken to investigate into the inter-state differentials in active case rates, recovery rates \& CFRs, role of selected demographic risk variables on case-load and trends in active cases in top 10 most affected States.
\end{abstract}

Material \& methods: COVID-19 data on confirmed cases, recovered (cured) cases, deaths and active cases from Indian States, as on $27^{\text {th }}$ October 2020, were down loaded from the official website of the Government of India. Data on selected demographic risk variables of COVID-19 disease were also obtained from country's 2011 Census. Such data were analyzed for case-loads, case- rates and weekly growth in active cases to understand the dynamics of COVID-19 pandemic.

Results: Active case load was 68 per 1,00,000 population in top 10 highly affected States by COVID-19, as compared to rest of the Indian States ( 28 per 1,00,000 population), with C.F.R. (weighted average) being $1.71 \%$ and $1.38 \%$ in the two groups of States respectively. COVID-19 active cases were highest-around 301 per 1,00,000 population in Puducherry, followed by Kerala (281/1,00,000 population), Ladakh (252/1,00,000 population) and Goa (173/1,00,000 population). The best State amongst 10 highly affected States for COVID-19 was Uttar Pradesh with minimum active case load of 13 per 1,00,000 population, followed by Odisha (37/1,00,000 population), Tamil Nadu (41 per 1,00,000 population) whereas, in rest of the States of the country, best State was Dadra Nagar \& Haveli and Daman \& Diu (with active case load of 9/1,00,000 population), followed by Bihar (9/1,00,00 population), Madhya Pradesh $(15 / 1,00,000)$ and then Punjab $(15 / 1,00,000)$. Furthermore, Kerala, Delhi, Karnataka and West Bengal were worse in controlling the COVID-19 disease.

Conclusion: Spread of COVID-19 disease has been steady and consistent throughout the country. Major burden of disease has been from 10 most affected States. COVID-19 case load increased almost continuously in different States but growth of the disease in them was slower-indicating better condition of the disease dynamics in our country than in many other countries of the world. It however, needs intense efforts from us to contain the disease in our country.

Keywords: COVID-19 disease, active case ratio, trend, case fatality ratio
Volume I2 Issue I - 202 I

\begin{abstract}
Pradyuman Verma,' Jang Bahadur Prasad, ${ }^{2}$ Naresh K Tyagi ${ }^{3}$

'Ph.D. Scholar, Department of Epidemiology and Biostatistics, KLE Academy of Higher Education and Research, India ${ }^{2}$ Assistant Professor, Department of Epidemiology and Biostatistics, KLE Academy of Higher Education and Research, India

${ }^{3}$ Professor and Head, Department of Epidemiology and Biostatistics, KLE Academy of Higher Education and Research, India
\end{abstract}

Correspondence: Jang Bahadur Prasad, Assistant Professor, Department of Epidemiology and Biostatistics, KLE Academy of Higher Education and Research, Belgaum- 590010, Karnataka, India,Tel +91 7349310589, Email jbiips I2@gmail.com

Received: February 16, 2021 | Published: March 23, 202 |

\section{Introduction}

Severe Acute Respiratory Syndrome Corona virus 2 (SARS$\mathrm{CoV}-2)$ is named as Corona-virus that causes Corona virus disease 2019 (COVID-19). Corona virus disease is transmitted from people to people through respiratory droplets and contact routes. ${ }^{1}$ Droplet transmission occurs through close contacts with someone who has COVID-19 symptoms. Hence, Corona virus disease transmission occurs by direct contact with infected people or by contacts with surfaces in the immediate environment or objects, used by infected persons. Thus, people may acquire Corona virus disease through air or after touching contaminated objects even after hours. ${ }^{2}$ Airborne transmission of the disease could be possible in specific circumstances and settings. WHO declared outbreak of COVID-19 disease a Public Health Emergency of International Concern on 30 January 2020.

Novel Corona Virus (nCoV) is a provisional name, which has been given to Corona viruses. The word 'novel' indicates a new pathogen of a previously known family of viruses. 'COVID-19' is the name, given by WHO officially, to Corona virus disease. ${ }^{4}$ Here, 'co' and 'vi' come from Corona Virus with 'd' meaning disease and '19' stands for year 2019. Common symptoms of the COVID-19 disease are fever, cough, headache, shortness of breath and loss of taste, etc. Due to huge impact of the disease on different aspects of human life, novel Corona Virus disease (COVID-19) has been most talked about, among infectious diseases.

At present, 218 countries and territories around the world, are affected from the COVID-19. In India, its first case was diagnosed in the State of Kerala on $30^{\text {th }}$ January 2020. Since then, graph of COVID-19 cases in the country increased almost exponentially. The swift response of the Government of India, however, has reasonably contained the rapid progress of the infection. The Government of India had announced nationwide 'lockdown' from 25th March 2020 to 31 May 2020 in 4 phases to contain the Covid19 disease. The $5^{\text {th }}$ phase of lockdown was limited to containment zones only. The consequences 
of lockdowns have been enormous and have generated economic and livelihood crisis in the country. Despite necessary control measures, a regular increase in the COVID-19 cases and deaths in different parts of the country have been observed, requiring necessary care from the Government machinery.

In India, as on 27 October 2020, the worst affected States from COVID-19 disease have been 10 (9 States and 1 UT). These are Maharashtra, Kerala, Karnataka, West Bengal, Tamil Nadu, Andhra Pradesh, Uttar Pradesh, Delhi, Telangana, and Odisha, considering the load of COVID-19 confirmed cases per 1,00,000 population. In view of huge impact of COVID-19 on human life including economic state of the country, the present study was undertaken to assess the inter-state differentials in COVID-19 confirmed cases, recovery rates, active case rates \& CFRs, look into the role of selected demographic variables on the case loads and to study trends in the active case ratios to understand the COVID-19 pandemic, to some extent.

\section{Material and methods}

The study - data on COVID-19 disease viz., total confirmed cases, total recovered cases, and total deaths, as available on $27^{\text {th }}$ October 2020, were extracted from the official website of the Government of India. ${ }^{5,6}$ To study the prevalent differentials of COVID-19 disease amongst different States of the country, data were downloaded from another similar website. ${ }^{7}$ The data on States' population for demographic risk variables were extracted from 2011 Census of India. $^{8}$

The active cases of Covid19 were computed as:

Activecases $=$ Confirmed cases $-($ Cured cases + Deaths $)$

Active case ratio (ACR) per week was computed as:

$$
\mathrm{ACR}=\frac{E A C_{i+7}}{E A C_{i}}
$$

Where, $E A C_{i+7}=$ Expected Active Cases at $(i+7)^{\text {th }}$ day and $E A C_{i}$ $=$ Expected Active Cases on $i^{\text {th }}$ day. Here, 7-day Active Case Ratios,

Table I COVID-19 load* in different states of India as on 27 October 2020 in place of 1-day Active Case Ratios, were used to get a magnifiable change in the index and to minimize the misreporting.

Active case ratio is expected to take values $\geq 0$; here ' 0 ' indicates no case of Covid19, ' 1 ' indicates peak level of COVID-19, and more than ' 1 ' indicates the increasing trend in cases of COVID-19.

Case Fatality Ratio (C.F.R.), which is at times, also loosely called as Case Fatality Rate, is often defined as the proportion of individuals who die of the disease, out of those who were diagnosed with same disease, and therefore, can be taken as a measure of severity in the detected cases. It may be indicated that this definition of the C.F.R. is applicable only under 2 assumptions: a) likelihood of the detection of cases and of deaths is consistent over the course of outbreak and that b) all reported cases have either recovered or died. This is however, not the case in an ongoing epidemic. Thus, in an ongoing epidemic, the above definition of C.F.R. cannot be applied. In our case, an alternative definition for computation of CFR, which should be applied ${ }^{9}$ for an ongoing epidemic like the present one, has been used here. Its formula is given below:

$$
C F R=\frac{\text { Deaths }}{(\text { Cured }+ \text { Deaths })} \times 100
$$

\section{Results}

Data on COVID-19 disease of different Indian States were grouped in two broad categories: (i) for top 10 highly affected States and (ii) for rest of States of the country. As on 27 October2020, top 10 highly affected States were identified, based on COVID-19 total confirmed cases. Such States were-Maharashtra, Kerala, Karnataka, West Bengal, Tamil Nadu, Andhra Pradesh, Uttar Pradesh, Delhi, Telangana and Odisha. COVID-19 data for both the above groups of States and for each of the affected Indian States are given in Table 1. Different affected States, shown in Table 1, are arranged according to the total confirmed cases of the disease as on 27 October 2020. Table 1 also gives total COVID-19 confirmed cases, cured cases (recovered cases), active cases and deaths for different affected States as well as for both the above broad groups (with States within the group, taken

\begin{tabular}{|c|c|c|c|c|c|c|c|}
\hline \multirow[b]{2}{*}{ State/U.T. } & \multirow{2}{*}{$\begin{array}{l}\text { Confirmed } \\
\text { Cases }\end{array}$} & \multicolumn{2}{|l|}{ Cured cases } & \multicolumn{2}{|l|}{ Active cases } & \multicolumn{2}{|l|}{ Deaths } \\
\hline & & Number (n) & $\begin{array}{l}\text { (Per I00 } \\
\text { Confirmed Cases) }\end{array}$ & Number (n) & $\begin{array}{l}\text { (Per I, 00,000 } \\
\text { Population) }\end{array}$ & Number (n) & $\begin{array}{l}\text { Case Fatality } \\
\text { Ratio (\%) }\end{array}$ \\
\hline All India & $79,46,429$ & $72,01,070$ & 90.62 & $6,25,857$ & 51.7 & $1,19,502$ & 1.63 \\
\hline $\begin{array}{l}\text { Top I } 0 \text { highly } \\
\text { affected States\# }\end{array}$ & $60,73,219$ & $54,92,840$ & 90.44 & $4,84,834$ & 67.96 & 95,545 & 1.71 \\
\hline Maharashtra & $16,48,665$ & $14,70,660$ & 89.2 & I,34,657 & 119.83 & 43,348 & 2.86 \\
\hline Andhra Pradesh & $8,08,924$ & $7,73,548$ & 95.63 & 28,770 & 58.03 & 6,606 & 0.85 \\
\hline Karnataka & $8,05,947$ & $7,19,558$ & 89.28 & 75,442 & 123.48 & 10,947 & 1.5 \\
\hline Tamil Nadu & $7,|1,7| 3$ & $6,71,489$ & 94.35 & 29,268 & 40.57 & 10,956 & 1.61 \\
\hline Uttar Pradesh & $4,72,077$ & $4,38,521$ & 92.89 & 26,652 & 13.34 & 6,904 & 1.55 \\
\hline Kerala & $3,97,217$ & $3,02,017$ & 76.03 & 93,848 & 280.93 & 1,352 & 0.45 \\
\hline Delhi & $3,59,488$ & $3,27,390$ & 91.07 & 25,786 & 153.6 & 6,312 & 1.89 \\
\hline West Bengal & $3,53,822$ & $3,10,086$ & 87.64 & 37,190 & 40.74 & 6,546 & 2.07 \\
\hline Odisha & $2,82,695$ & $2,66,105$ & 94.13 & $|5,33|$ & 36.52 & 1,259 & 0.47 \\
\hline Telangana & $2,32,671$ & $2,13,466$ & 91.75 & 17,890 & 51.11 & 1,315 & 0.61 \\
\hline
\end{tabular}
together) 
Table Continued..

\begin{tabular}{|c|c|c|c|c|c|c|c|}
\hline \multirow{2}{*}{ State/U.T. } & \multirow{2}{*}{$\begin{array}{l}\text { Confirmed } \\
\text { Cases }\end{array}$} & \multicolumn{2}{|l|}{ Cured cases } & \multicolumn{2}{|l|}{ Active cases } & \multicolumn{2}{|l|}{ Deaths } \\
\hline & & Number (n) & $\begin{array}{l}\text { (Per I00 } \\
\text { Confirmed Cases) }\end{array}$ & Number (n) & $\begin{array}{l}\text { (Per I,00,000 } \\
\text { Population) }\end{array}$ & Number (n) & $\begin{array}{l}\text { Case Fatality } \\
\text { Ratio (\%) }\end{array}$ \\
\hline Rest other States & $18,73,210$ & $17,08,230$ & 91.19 & $I, 4 I, 023$ & 28.37 & 2,397 & 1.38 \\
\hline Bihar & $2,12,355$ & $2,01,942$ & 95.1 & 9,355 & 8.99 & 1,058 & 0.52 \\
\hline Assam & $2,04,386$ & $\mathrm{I}, 88,587$ & 92.27 & $|4,89|$ & 47.72 & 908 & 0.48 \\
\hline Rajasthan & $\mathrm{I}, 88,048$ & $1,69,962$ & 90.38 & 16,233 & 23.68 & 1,853 & 1.08 \\
\hline Chhattisgarh & $1,77,608$ & $\mathrm{I}, 53,654$ & 86.51 & 22,093 & 86.49 & $|, 86|$ & 1.2 \\
\hline Madhya Pradesh & $1,67,969$ & $\mathrm{I}, 54,222$ & 91.82 & 10,857 & 14.95 & 2,890 & 1.84 \\
\hline Gujarat & $1,67,919$ & $1,50,513$ & 89.63 & 13,716 & 22.69 & 3,690 & 2.39 \\
\hline Haryana & I,59,457 & $\mathrm{I}, 47,566$ & 92.54 & 10,154 & 40.05 & $\mathrm{I}, 737$ & 1.16 \\
\hline Punjab & I,31,39| & $\mathrm{I}, 23,047$ & 93.65 & 4,219 & $|5.2|$ & 4,125 & 3.24 \\
\hline Jharkhand & 99,906 & 93,368 & 93.46 & 5,666 & 17.18 & 872 & 0.93 \\
\hline Jammu \& Kashmir & 92,225 & 83,485 & 90.52 & 7,296 & 59.48 & $\mathrm{I}, 444$ & 1.7 \\
\hline Uttarakhand & 60,744 & 55,663 & 91.64 & 4,080 & 40.45 & $\mathrm{I}, 00 \mathrm{I}$ & 1.77 \\
\hline Goa & 42,532 & 39,433 & 92.71 & 2,517 & 172.57 & 582 & 1.45 \\
\hline Puducherry & 34,336 & 29,990 & 87.34 & 3,758 & 301.13 & 588 & 1.92 \\
\hline Tripura & 30,293 & 28,153 & 92.94 & I,796 & 48.89 & 344 & 1.21 \\
\hline Himachal Pradesh & 20,586 & 17,782 & 86.38 & $2,51 I$ & 36.58 & 293 & 1.62 \\
\hline Manipur & 17,424 & 13,057 & 74.94 & 4,223 & 164.29 & 144 & 1.09 \\
\hline Chandigarh & 14,085 & 13,230 & 93.93 & 633 & 59.97 & 222 & 1.65 \\
\hline Meghalaya & 9,066 & $7,47 \mid$ & 82.41 & $|, 5| 4$ & 51.03 & 81 & 1.07 \\
\hline Nagaland & 8,663 & 6,792 & 78.4 & I,838 & 92.9 & 33 & 0.48 \\
\hline Ladakh & 5,978 & 5,216 & 87.25 & 691 & 252.19 & 71 & I.34 \\
\hline $\begin{array}{l}\text { Andaman and } \\
\text { Nicobar Islands }\end{array}$ & 4,253 & 3,997 & 93.98 & 198 & 52.03 & 58 & 1.43 \\
\hline Sikkim & 3,840 & 3,530 & 91.93 & 245 & 40.13 & 65 & 1.81 \\
\hline $\begin{array}{l}\text { Dadra \& Nagar Haveli } \\
\text { and Daman \& Diu }\end{array}$ & 3,228 & 3,176 & 98.39 & 50 & 8.54 & 2 & 0.06 \\
\hline Mizoram & 2,527 & 2,212 & 87.53 & 315 & 28.7I & Nil & 0 \\
\hline
\end{tabular}

Note: *Data Sources: References 5 \& 6

\#Top 10 highly affected States of India: Maharashtra, Kerala, Karnataka,West Bengal,Tamil Nadu, Andhra Pradesh, Uttar Pradesh, Delhi, Telangana, and Odisha

\section{COVID-I9 active case load in different states}

Top 10 highly affected States had more than double COVID-19 active cases (around 68/1,00,000 population) against rest of the States of the country (28 active cases/1,00,000 population). Thus, major burden of the COVID-19 cases in the country has been mainly from disease active case load in top 10 highly affected States of the country. Further, amongst top 10 highly affected States, COVID-19 active case rate was highest in Kerala (281 active cases/1,00,000 population), followed by Delhi ( 154 active cases/1,00,000 population), Karnataka (124 active cases/1,00,000 population) and then Maharashtra (120 active cases/1,00,000 population). In other States of this group, active case rate ranged between 13 active cases/1,00,000 population (in Uttar Pradesh) and 58 active cases/1,00,000 population (in Andhra Pradesh). However, in the other group of States (i.e., in the rest of the States), active case rate fluctuated greatly. The highest active case rate was seen for Puducherry (301 active cases/1,00,000 population), followed by Ladakh (252 active cases/1,00,000 population), Goa (173 active cases/1,00,000 population), Manipur (164 active cases $/ 1,00,000$ population) and then Arunachal Pradesh (157 active cases $/ 1,00,000$ population). The active case rate in other States of this group, ranged between 9 active cases/1,00,000 population (Dadra \& Nagar Haveli and Daman \& Diu) and 93 active cases/100,000 population (Nagaland) (Table 1). 


\section{Recovery status of the COVID-I 9 cases in different states}

The overall recovery rate (i.e., cure rate) in the top 10 highly affected States was 90 per 100 COVID-19 confirmed cases against 91 per 100 confirmed cases in the rest of the States. In the former group of States (i.e., in top 10 highly affected States), the highest recovery rate was in Andhra Pradesh (96/100 confirmed cases), followed by Tamil Nadu (94/100 confirmed cases) and then Odisha (94/100 confirmed cases). However, in the latter group (i.e., in the rest of the States), the highest recovery rate was for Dadra \& Nagar Haveli and Daman \& Diu (98.39/100 confirmed cases), followed by Bihar (95/100 confirmed cases), and Jharkhand, Punjab, Chandigarh \& Andaman-Nicobar Islands (94/100 confirmed cases, in each case). In other States of this group, recovery rates ranged between $75 / 100$ confirmed cases (in Manipur) and 93/100 confirmed cases (in eachHaryana, Tripura \& Goa) (Table 1).

\section{States' differentials of COVID-I 9 fatality status}

C.F.R. of COVID-19 disease in top 10 highly affected cases was $1.71 \%$ against 1.38 in the other group (i.e., in the rest of the States). Thus, top 10 highly affected States showed a slightly higher risk of fatality in COVID-19 cases than their counter parts. Further, if we view State-wise fatality differentials in the country, we find a highest COVID-19 C.F.R. for Punjab (3.24\%), followed by Maharashtra $(2.86 \%)$ and then Gujarat (2.39\%). Mizoram did not witness even a single death amongst COVID-19 cases till 27 October 2020. C.F.R. ranged between $0.06 \%$ (in Dadra-Nagar Haveli \& Daman-Diu and $2.07 \%$ (in West Bengal) (Table 1).

\section{COVID-I 9 disease and some of its demographic risk variables}

Table 2 reveals that 10 Indian States which were highly affected from COVID-19 disease comprised of $58.9 \%$ of the country's population with population density of 499 per square kilometer as against $41.1 \%$ of the population proportion and with population density of 268 per square population in the rest of the States. Thus, population proportion as well as population density have been higher in the first group of 10 States (which were highly affected from COVID-19 disease) than the second one. Similarly, the proportion of urbanization (35\%), sex-ratio (955 females/1,000 males) and proportion of senior citizens (9\%) were also higher in the 10 highly affected States than their counterparts (25\%, 924 females $/ 1,000$ males $\& 8 \%$ respectively).

Table 2 Some demographic risk variables* of COVID-19 in top 10 highly affected states\# of the country

\begin{tabular}{lll}
\hline $\begin{array}{l}\text { Demographic risk } \\
\text { variables }\end{array}$ & $\begin{array}{l}\text { In Top I0 } \\
\text { highly affected } \\
\text { states of the } \\
\text { country }\end{array}$ & $\begin{array}{l}\text { In rest of the } \\
\text { country's } \\
\text { states }\end{array}$ \\
\hline $\begin{array}{l}\text { Population proportion (\%) } \\
\begin{array}{l}\text { Population density (People per } \\
\text { square km.) }\end{array}\end{array}$ & 58.9 & 41.1 \\
$\begin{array}{l}\text { Urbanization (\%) } \\
\begin{array}{l}\text { Sex ratio (Females per I,000 } \\
\text { males) }\end{array}\end{array}$ & 35.11 & 268 \\
$\begin{array}{l}\text { Population, aged 60+ years (\%) } \\
\text { Pas }\end{array}$ & 9.13 & 25.45 \\
\hline
\end{tabular}

Note: *Data source: Reference 8

\#As on 27 October 2020, top 10 highly affected States were: Maharashtra, Kerala, Karnataka, West Bengal, Tamil Nadu, Andhra Pradesh, Uttar Pradesh, Delhi, Telangana and Odisha

\section{Weekly active case ratio in Top I 0 highly affected states}

Table 3 and Figure 1a, 1b \& 1c show COVID-19 weekly active case ratio for 10 highly affected States. It may be seen here that Tamil Nadu was in worst position in controlling COVID-19 as on $22^{\text {nd }}$ and $29^{\text {th }}$ days with weekly active case ratios being 18.5 and 10.9 respectively. Thereafter, situation was almost under control up to $57^{\text {th }}$ day but cases again increased on $64^{\text {th }}$ day, cases remained almost steady up to $113^{\text {th }}$ day and thereafter, there was some decrease in case load with occasional fluctuations. Maharashtra was in the worst situation for controlling the disease on $8^{\text {th }}$ day with some fluctuations till $43^{\text {th }}$ day and thereafter, the case load decreased. Similarly, Karnataka was in worst situation on $8^{\text {th }}$ day $\& 15^{\text {th }}$ day with weekly active case ratio being $5.0 \& 6.0$ respectively and thereafter, it started decreasing. Andhra Pradesh, similarly, was in bad state of affairs between $15^{\text {th }}$ and $29^{\text {th }}$ days, with weekly active case ratios lying between $8 \& 4$, reaching to the peak on $22^{\text {nd }}$ day and thereafter, cases were under control.

Table 3 Active case ratios of COVID-19 in 10 most affected states

\begin{tabular}{llllllllllll}
\hline Days & Maharashtra & Karnataka & $\begin{array}{l}\text { Andhra } \\
\text { Pradesh }\end{array}$ & $\begin{array}{l}\text { Tamil } \\
\text { Nadu }\end{array}$ & $\begin{array}{l}\text { Uttar } \\
\text { Pradesh }\end{array}$ & Kerala & Delhi & $\begin{array}{l}\text { West } \\
\text { Bengal }\end{array}$ & Odisha & Telangana \\
\hline$* 1$ & 2 & 1 & 1 & 1 & 6 & 1 & 1 & 1 & 1 & 1 \\
8 & 16 & 5 & 2 & 1 & 1.5 & 3 & 4 & 8 & 2 & 1 & \\
15 & 2.25 & 6 & 5 & 2 & 1.22 & 1 & 1 & 3.5 & 1.5 & 2 & \\
22 & 2.29 & 2.5 & 8.4 & 18.5 & 2.36 & 1 & 5.75 & 2.89 & 6.33 & 15.5 & \\
29 & 3.92 & 1.8 & 4.02 & 10.89 & 3.35 & 1 & 3.43 & 2.09 & 2.16 & 2.23 & \\
36 & 2.5 & 1.35 & 1.48 & 2.13 & 3.61 & 0 & 6.29 & 1.98 & 1.05 & 4.06 & 1.59 \\
43 & 2.15 & 1.47 & 1.45 & 1.19 & 2.14 & 0 & 2.22 & 1.74 & 1.67 & 1.59 \\
50 & 1.88 & 1.13 & 1.45 & 0.85 & 1.82 & 1.71 & 1.51 & 1.44 & 1.42 & 1.48 \\
57 & 1.58 & 1.03 & 0.96 & 1.37 & 1.31 & 4.67 & 1.19 & 1.62 & 3 & 1.05 \\
64 & 1.66 & 1.26 & 0.94 & 3.68 & 1.15 & 2.13 & 1.57 & 1.2 & 1.97 & 0.81 \\
71 & 1.41 & 1.53 & 0.96 & 1.7 & 0.93 & 1.09 & 1.53 & 1.37 & 1.29 & 0.74 \\
\hline
\end{tabular}


Table Continued...

\begin{tabular}{|c|c|c|c|c|c|c|c|c|c|c|}
\hline Days & Maharashtra & Karnataka & $\begin{array}{l}\text { Andhra } \\
\text { Pradesh }\end{array}$ & $\begin{array}{l}\text { Tamil } \\
\text { Nadu }\end{array}$ & $\begin{array}{l}\text { Uttar } \\
\text { Pradesh }\end{array}$ & Kerala & Delhi & $\begin{array}{l}\text { West } \\
\text { Bengal }\end{array}$ & Odisha & Telangana \\
\hline 78 & 1.41 & 2.32 & 1.16 & 1.01 & 1.1 & 0.64 & 1.13 & 1.53 & 1.05 & 1.26 \\
\hline 85 & 1.06 & 1.4 & 1.46 & 1.17 & 1.42 & 0.66 & 1.22 & 1.45 & 1.17 & 1.35 \\
\hline 92 & 1.21 & 1.67 & 1.48 & 1.45 & 1.16 & 1.11 & 1.65 & 1.09 & 1.25 & 1.67 \\
\hline 99 & 1.22 & 0.91 & 1.46 & $\mathrm{I} .44$ & 1.4 & 0.24 & 1.49 & 0.92 & 1.2 & 1.47 \\
\hline 106 & 1.13 & 1.15 & 1.63 & 1.29 & 1.16 & 1.33 & 1.48 & 1.17 & 1.3 & 1.38 \\
\hline 113 & 1.17 & 1.61 & 1.49 & 1.37 & 1.22 & 4 & 1.02 & 1.26 & 1.52 & 1.6 \\
\hline 120 & 1.22 & 2.42 & 1.35 & 1.33 & 1.08 & 2.78 & 1.13 & 1.65 & 1.53 & 2.33 \\
\hline 127 & 1.21 & 1.72 & 1.53 & 1.07 & 1.42 & 1.87 & 0.9 & 1.49 & 1.14 & 1.21 \\
\hline 134 & 1.24 & 1.73 & 1.91 & 1.04 & 1.45 & 1.49 & 0.77 & 1.09 & 1.73 & 1.09 \\
\hline $14 \mid$ & 1.15 & 1.48 & 2.01 & 1.11 & 1.47 & 1.09 & 0.84 & 1.14 & 1.51 & 1.03 \\
\hline 148 & I & 1.28 & 1.26 & 1.09 & 1.38 & 1.25 & 0.74 & 1.16 & 1.09 & 1 \\
\hline 155 & 0.98 & 1.09 & 1.12 & 0.91 & 1.48 & 1.26 & 0.87 & 1.07 & 1.26 & $\mid .51$ \\
\hline 162 & 1.09 & 1.01 & 0.96 & 1.02 & 1.19 & 1.22 & 1.04 & 0.99 & 1.36 & 1.21 \\
\hline 169 & 1.08 & 1.03 & 1.06 & 0.99 & 1.03 & 1.87 & 1.01 & 0.91 & 1.15 & 0.95 \\
\hline 176 & 1.13 & 1.05 & 1.12 & 0.98 & 0.99 & 1.81 & 1.09 & 0.94 & I & 1.07 \\
\hline 183 & 1.22 & 1.13 & 0.94 & 0.98 & 1.12 & 1.17 & 1.26 & 1.03 & 1.16 & 1.37 \\
\hline 196 & 1.26 & 0.99 & 0.73 & 0.9 & 1.21 & 1.23 & 1.9 & 1.08 & 1.09 & 1.01 \\
\hline 203 & 0.9 & 1.03 & 0.83 & I & 0.95 & 1.28 & 1.14 & 1.07 & 0.88 & 0.97 \\
\hline 210 & 0.96 & I.II & 0.85 & I & 0.84 & 1.3 & 0.93 & I.I & 0.81 & 0.99 \\
\hline 217 & 0.86 & 1.07 & 0.84 & 0.96 & 0.83 & 1.06 & 0.85 & 1.13 & 0.86 & 0.92 \\
\hline 224 & 0.84 & 0.91 & 0.78 & 0.94 & 0.86 & 1.03 & 0.87 & 1.08 & 0.78 & 0.92 \\
\hline 231 & 0.76 & 0.78 & & 0.82 & 0.81 & 1.34 & 1.04 & & & 0.86 \\
\hline 238 & & & & & 0.85 & 1.3 & 1.16 & & & 0.88 \\
\hline 245 & & & & & & 1.53 & & & & \\
\hline 252 & & & & & & 1.42 & & & & \\
\hline 259 & & & & & & 1.09 & & & & \\
\hline 266 & & & & & & 0.96 & & & & \\
\hline
\end{tabular}

Note: ${ }^{*}$ Cases on Ist Day $^{\text {st }}$

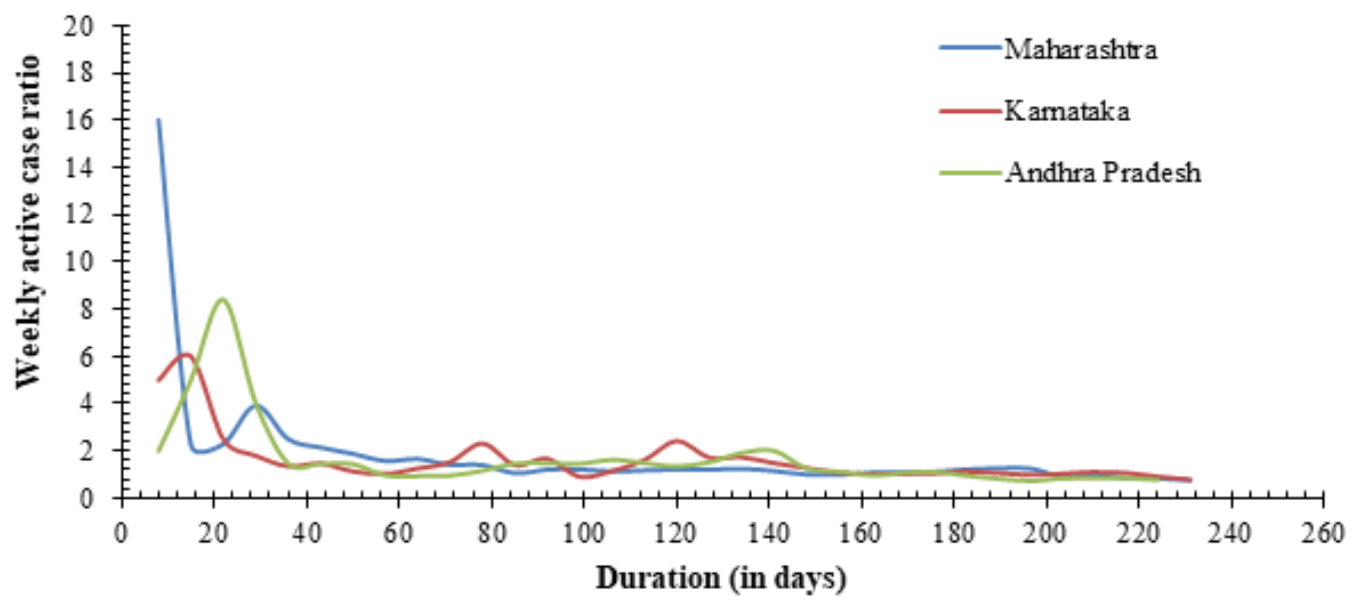

Figure I a Weekly active case ratio (I March 2020 - 27 October 2020).

Citation: Verma P, Prasad JB, Tyagi NK. A study on disease dynamics of covid-19 in different states of India:A data driven analysis of the available evidence.J Cancer Prev Curr Res. 202 I;12(I):36-42. DOI: 10.15406/jcpcr.202I.I2.0045 I 


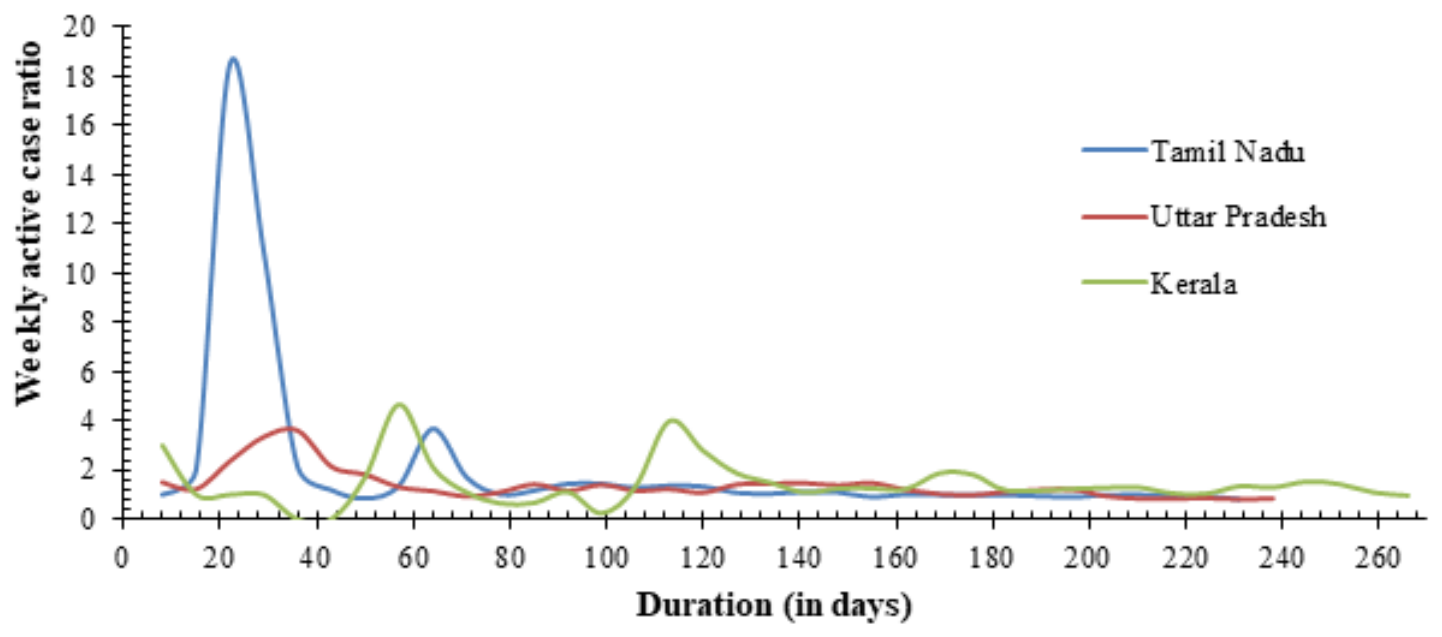

Figure Ib Weekly active case ratio; (I March 2020 - 27 October 2020).

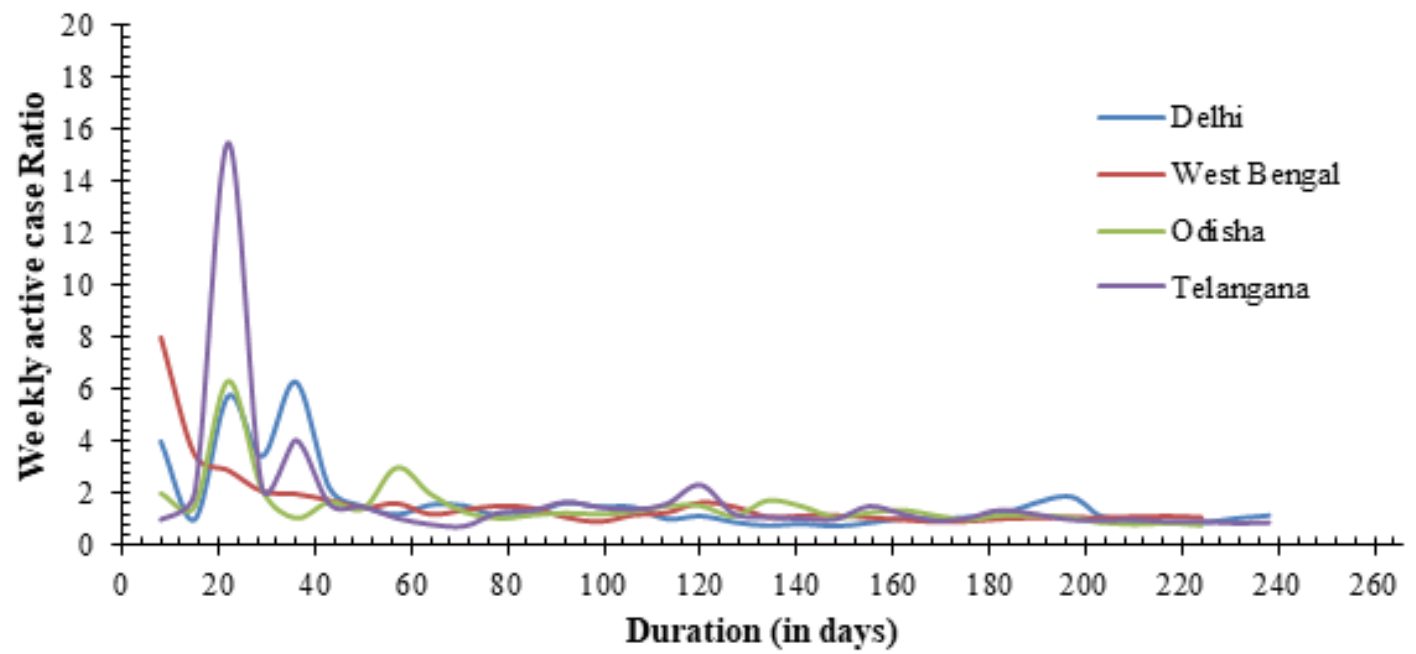

Figure Ic Weekly active case ratio; (I March 2020 - 27 October 2020).

In Uttar Pradesh, a relatively higher case load was seen between $29^{\text {th }}$ and $43^{\text {th }}$ days with weekly active case ratios, lying between 2 and 4 and thereafter, it fluctuated within the smaller range (0.8-2.1). In Kerala, a high case load was seen on $57^{\text {th }}$ and $113^{\text {th }}$ days with weekly active case ratios being 4.7 and 4.0 respectively. On other days however, this ratio ranged between 0.2 and 3.0. As shown in Figure 1c (Table 3), Delhi was worst in controlling COVID-19 on $22^{\text {nd }}$ day with weekly active case ratio being 5.8 , and on $36^{\text {th }}$ day, it became 6.3 . Thereafter, COVID-19 cases fluctuated in a smaller range. In West Bengal, weekly active case ratio was highest $(8.0)$ on the $8^{\text {th }}$ day and after $15^{\text {th }}$ day; such ratio started decreasing. In fact, it fluctuated within smaller range thereafter - indicating better control of disease during the study period. In Odisha, highest case load was seen on $22^{\text {th }}$ day with weekly active case ratio being 6.3 and thereafter, COVID-19 cases decreased with some fluctuations. Similarly, in Telangana also, highest active case ratio was seen on $22^{\text {th }}$ day with weekly active case ratio of 15.5 .

\section{Discussion}

COVID-19 spread exponentially world over with no let up during the study period and has varying intensity across the countries; with minimum in Anguilla (3) and maximum in USA $(7,447,693) \cdot{ }^{10}$ Burden of COVID-19 disease in India increased fast from first case on $30^{\text {th }}$
January 2020 to $79,46,429$ confirmed cases, 1,19,502 deaths and $6,25,857$ active cases as on 27 October 2020 . Its case fatality ratio (CFR) varied from $0.06 \%$ in Dadra \& Nagar Haveli and Daman \& Diu to the maximum of $3.24 \%$ in Punjab, despite stringent measures, like lockdown etc., promptly taken by the Government. ${ }^{11}$ Actions of the Government of India were praised as 'tough \& timely' by the WHO. ${ }^{12}$

Researchers from different domains studied transmission dynamics of COVID-19, built statistical models and also made some useful predictions, like-disease grew exponentially ${ }^{13}$ etc. Prasad et al., ${ }^{14}$ have also modified the existing exponential/quadratic models- by accommodating period of containment of disease, without taking any specific action at micro level. The present study was undertaken to assess the COVID-19 disease status \& its inter-state differentials as on 27 October 2020 and to study trends of its active cases, to understand the dynamics of disease-pandemic. The results of the study may motivate the Union as well as State Government to take measures in disease management by considering the disease-burden at different levels.

Top 10 highly affected States (taken together) were responsible for $76 \%$ of total COVID-19 confirmed cases and $80 \%$ of the total COVID-19 deaths in the country. Kerala was worst affected State, 
with an active case rate of $281 / 1,00,000$ population but had a quite low CFR of $0.45 \%$. This was followed by Karnataka (124 active cases per $1,00,000$ population \& CFR $=1.50 \%$ ) and Maharashtra (120 active cases per $1,00,000$ population \& CFR $=2.86 \%)$. As regards, status of active case rates in other States which were highly affected from COVID-19, this followed, in order, by West Bengal, Tamil Nadu, Andhra Pradesh, Uttar Pradesh, Delhi, Telangana \& Odisha. Their active case rates as well as CFRs, though varied yet, showed downward trend. As against this, active case rates amongst the 'less affected States', Puducherry had the highest active case rate $(301 / 1,00,000$ population), followed by Goa $(173 / 1,00,000$ population), Manipur (164/1,00,000 population) and then Arunachal Pradesh (157/1,00,000 population). CFR in Punjab was $3.24 \%$ however, in rest of the States of this group; it remained within the smaller range (below $2.39 \%$ ). Here, though it is difficult to cause out the differentials of COVID-19 active case rates as well as CFRs, yet labour movement could be the one possibility for this-particularly in top 10 highly COVID-19 affected States. Further, demographic variables, like - population density, urbanization, sex-ratio and proportion of the aged population, along with turbulent labour unrest in some States, might have contributed considerably to the high active case rates as well as high fatality rates due to COVID-19.

The COVID-19 case load increased nearly continuously in different States but growth of the disease in them was slower indicating better condition of the disease dynamics in our country than in many other countries of the world. Veena Das (2020) also indicates that virus and different control measures varied by different societies and population. Furthermore, experiences of governance were varying enormously across different regions of the world. ${ }^{15}$ Country's some States, namely-Tamil Nadu, Maharashtra and Telangana could not satisfactorily control the disease-at least in their initial days, as their weekly active case ratios went quite high, ranging between 16.019.0. More specifically, active case ratios were quite high in Tamil Nadu (18.5 on $22^{\text {nd }}$ day), Maharashtra ( 16.0 on $8^{\text {th }}$ day) and Telangana (15.50 on $22^{\text {th }}$ day. Amongst highly affected States, States like-U.P., West Bengal, Kerala \& Odisha were in better position in managing the disease-burden of COVID-19.

Findings of this Study may help in modifying the existing mathematical models, built to project COVID-19 cases and deathsparticularly in Indian context. It may be emphasized here that, as many of the built-in models do not correctly project current scenario of the disease in the country, models seem to have been constructed with bias and based on unrealistic assumptions. ${ }^{16}$ In order to get precise estimates of COVID-19, particularly of active cases and deaths, further research on mathematical models and their applications need to be undertaken to study the transmission dynamics of COVID-19.

\section{Conclusions}

Spread of COVID-19 has been slower throughout the nation in India as compared to some other world countries like USA, Italy, Brazil, Russia and Spain. In India, major burden of the COVID-19 has been due to ' 10 highly affected States, viz. Maharashtra, Kerala, Karnataka, West Bengal, Tamil Nadu, Andhra Pradesh, Uttar Pradesh, Delhi, Telangana, Odisha, with more than two and half times active case rate $(68 / 1,00,000)$, as compared to the country's remaining States which are relatively less affected from the disease $(28 / 1,00,000)$. For weekly active case ratios, fluctuations were highest in Telangana, followed by Tamil Nadu and then Maharashtra in controlling COVID-19. Hence, to contain COVID-19 in the country, further research on case management, immunization, case holding and consequences in terms of socio-psycho behavioural changes in the population, need to be properly studied.

\section{Ethical approval and consent to participate}

Not applicable.

\section{Consent for publication}

Not applicable.

\section{Funding}

Not received any funding.

\section{Acknowledgments}

None.

\section{Competing interests}

The authors declare that they have no conflict of interest.

\section{References}

1. World Health Organization. Report of WHO-China Joint Mission on Corona virus Disease 2019; 2020a. 16-24 p.

2. Gupta A, Kakkar R. Managing a Covid-19 patient at different health care and field level settings. Indian J Comm Health. 2020;32(2):188-195.

3. World Health Organization. Statement on the Second Meeting of the International Health Regulations: Emergency Committee regarding the Outbreak of Novel Corona virus (2019-nCoV); 2020.

4. Rothan HA, Byrareddy SN. The epidemiology and pathogenesis of Corona virus disease (Covid19) Outbreak. J Autoimmun. 2020;109:102433.

5. Corona Virus Outbreak in India.

6. Official Updates on Corona virus/Covid19 in India

7. COVID-19 in India: Kaggle.

8. Census 2011 India.

9. World Health Organization. Estimating Mortality from Covid19: Scientific Brief; 2020.

10. Covid19 Corona Virus Pandemic. Worldometers; 2020

11. Corona virus disease 2019 (Covid19). National Health Portal; 2020.

12. The Lancet. India under Covid19 Lockdown. Lancet. 2020;395(10233):1315.

13. Prasad JB, Biradar AR, Kumar A. Status and Impact of Covid19 Pandemic on Humans: Dynamics and Control. Epidemiology Int J. 2020;4(2):1-11.

14. Prasad JB, Tyagi NK, Patil AP. Dynamics of Covid19 Cases in India: A Statistical Model. Demography India. 2020;49:51-65.

15. Van Bavel, Jay J, Katherine Baicker, et al. Using social and behavioural science to support COVID-19 pandemic response. Nature Human Behaviour. 2020;4(5):460-471.

16. Bhatia R, Abraham P. Lessons learnt during the first 100 days of Covid19 pandemic in India. Indian Journal of Medical Research. 2020;151(5):387-391. 